\title{
AFIKSASI PADA KARANGAN ANAK USIA 10 - 12 TAHUN DI KUNINGAN, JAWA BARAT: SEBUAH KAJIAN MORFOLOGI
}

\author{
Praspati Riansyah \\ Endry Boeriswati \\ Aulia Rahmawati
}

\begin{abstract}
Abstrak. Penelitian ini bertujuan untuk memperoleh pemahaman yang mendalam tentang proses afiksasi dan perubahan kelas kata yang terdapat pada karangan anak umur 11 tahun di Kuningan, Jawa Barat. Penelitian ini dilakukan pada semester genap tahun 2014-2015.Metode yang digunakan dalam penelitian ini berupa metode deskriptif kualitatif dengan menggunakan teknik analisis isi. Penelitian ini difokuskan pada proses afiksasi dan perubahan kelas kata pada karangan anak umur 10-12 tahun di Kuningan, Jawa Barat. Objek penelitian adalah karangan anak umur 10-12 tahun di Kuningan, Jawa Barat. Instrumen penelitian yang digunakan adalah peneliti sendiri dibantu dengan tabel analisis kerja, yaitu tabel analisis proses afiksasi dan perubahan kelas kata. Hasil penelitian ini ditemukan bahwa proses morfologi dan perubahan kelas kata pada karangan anak umur 10-12 tahun di Kuningan, Jawa Barat menandakan bahwa proses morfologi dan perubahan kelas kata terdapat dalam pembuatan karangan oleh anak umur 11 tahun di Kuningan, Jawa Barat. Dengan demikian, proses morfologi dan perubahan kelas kata terdapat dalam karangan anak umur 10-12 tahun di Kuningan, Jawa Barat.
\end{abstract}

Kata Kunci: Afiksasi, Perubahan Kelas Kata, Karangan, Dananak Umur 10-12 Tahun.

\section{PENDAHULUAN}

Bahasa merupakan hal yang tidak pernah lepas dari kehidupan manusia.Bahasa mempunyai peran yang penting bagi manusia, selain sebagai alat komunikasi, bahasa juga digunakan untuk menjalankan setiap aktivitas manusia dalam berbagai bidang.Ilmu yang mempelajari bahasa disebut ilmu linguistik.Ilmu linguistik sering juga disebut linguistik umum.Artinya, ilmu linguistik tidak hanya mengkaji sebuah bahasa, seperti bahasa Sunda atau bahasa Prancis, tetapi mengkaji seluk beluk bahasa pada umumnya, bahasa yang menjadi alat interaksi sosial manusia. Membahas tentang bahasa sebagai alat komunikasi, tidak akan dapat lepas dari struktur bahasa. Struktur intern bahasa mencakup fonetik, fonologi, morfologi, sintaksis, dan semantik.

Morfologi merupakan ilmu bahasa yang mempelajari proses pembentukan kata. Di dalamnya terdapat proses morfologi, morfofonemik, dan klasifikasi kata. Proses morfologi terbagi atas proses afiksasi, proses reduplikasi, proses akronimisasi, dan proses konversi. Proses afiksasi terbagi lagi menjadi prefiksasi, infiksasi, sufiksasi, konfiksasi, dan klofiksasi.

Dalam menggunakan bahasa sebagai ujaran tidak hanya menggunakan kata dasar, ada pula kata yang dibentuk setelah melalui proses morfologi, yang salah satunya adalah proses afiksasi atau proses pembubuhan afiks pada kata dasar. Produksi ujaran memanfaatkan kata dasar dan kata bentukan yang berasal dari kata dasar yang telah melalui proses morfologi. 
Kata-kata, seperti memasukkan, pakaian, melarang, mengingatkan, bercerita, dan terkunci merupakan kata yang telah mengalami proses afiksasi. Kata-kata tersebut telah melalui proses pembubuhan morfem afiks pada morfem dasar. Seperti pada kata melarang, merupakan sebuah proses prefiksasi, yaitu morfem dasar larang dibubuhi oleh prefiks me-. Kata pakaian merupakan sebuah proses sufiksasi, yaitu morfem dasar pakai ditambahkan sufiks -an. Proses klofiksasi terjadi dalam pembentukan kata memasukkan dan mengingatkan, yaitu bentuk dasar masuk dan ingat ditambahkan klofiks me-kan.

Dalam karangan juga memanfaatkan kata dasar dan kata bentukan yang merupakan hasil proses morfologi, salah satunya proses afiksasi. Dalam karangan kita dapat melihat kemampuan anak dalam membentuk kata. Kemampuan ini dapat dilatih dengan menulis yang merupakan suatu proses untuk menuangkan ide dan gagasan terhadap suatu simbol grafis. Menurut Sabarti (1988) menulis merupakan suatu proses kegiatan yang bukan dilakukan dalam sekali jadi, proses itu mulai dari menemukan topik, membatasi topik, memecahkan topik, menjadi kerangka, dan mengembangkan kerangka menjadi sebuah karangan dan dapat dipahami oleh pembaca dengan mudah.

Pengetahuan tentang struktur-struktur bahasa tersebut memiliki peran bagi kemampuan berbahasa anak. Pada usia dini, kegiatan berbahasa anak mulai muncul dan tetap berlangsung terus dan subur. Otak dapat berfungsi cukup mudah dan lentur di dalam mengatur segala sesuatu yang diperlukan dalam proses penguasaan bahasa. Penting bagi seorang anak mengetahui bagaimana proses suatu kata terbentuk agar ia dapat berkomunikasi. Hal ini sangat dipengaruhi oleh kemampuan berbahasa anak.

Guna mengetahui proses afiksasi yang terjadi dalam proses pembentukan kata dan perubahan kelas kata yang mengalami proses afiksasi pada tulisan atau karangan diperlukan adanya penelitian. Karangan berasal dari anak umur 10-12 tahun, karena masa anak usia dua sampai dengan tiga belas tahun merupakan masa yang baik untuk proses kegiatan berbahasa anak. Kemampuan berbahasa anak Indonesia khususnya anak yang berumur 10-12 tahun pada umumnya sama. Anak berumur 10-12 tahun diajarkan empat aspek dalam kemampuan berbahasa, yaitu membaca, menulis, menyimak, dan berbicara dengan baik.Keempat aspek itulah yang mereka harus kuasai sejak dini.Untuk itulah diperlukan adanya penelitian terhadap kemampuan membentuk kata anak umur 10-12 tahun, sebab pada umur tersebut seharusnya seorang anak sudah mampu menguasai bahasa dengan baik.

\section{METODE PENELITIAN}

Metode yang digunakan dalam penelitian ini adalah metode deskriptif kualitatif dengan analisis isi, yaitu analisis proses afiksasi dan perubahan kelas kata pada karangan anak umur 10-12 tahun di Kuningan, Jawa Barat.

\section{PEMBAHASAN PENELITIAN}

Hasil analisis proses afiksasi yang terdapat pada karangan anak umur 10-12 tahun di Kuningan, Jawa Barat yaitu dari 20 karangan yang diambil dari tiga sekolah dasar di Kuningan, Jawa Barat diperoleh data sebanyak 164 buah kata yang mengalami proses afiksasi. Fokus penelitian ini adalah pada proses afiksasi yang terbagi atas prefiks, infiks, sufiks, konfiks, dan klofiks.

Dalam bahasa Indonesia, proses morfologi pada bentuk dasar meliputi afiksasi, reduplikasi, komposisi, dan akronimisasi. Dari proses-proses tersebut, afiksasi terbagi lagi 
menjadi lima, yaitu prefiks, infiks, sufiks, konfiks, dan klofiks. Dalam penelitian ini ditemukan sebanyak 164 buah data proses afiksasi pada karangan anak umur 10-12 tahun di Kuningan, Jawa Barat. Sebanyak 164 buah data afiksasi tersebut terbagi atas prefiks 85 buah kata $(51,8 \%)$, infiks 0 buah kata $(0 \%)$, sufiks 15 buah kata $(9,1 \%)$, konfiks 22 buah kata $(13,4 \%)$, dan klofiks 42 buah kata $(25,7 \%)$.

Proses prefiksasi dengan kemunculan $51,8 \%$ dari keseluruhan data yang ditemukan merupakan proses afiksasi yang paling sering muncul pada karangan anak umur 10-12 tahun di Kuningan, Jawa Barat dibandingkan dengan proses afiksasi lainnya. Adapun bentuk proses afiksasi yang paling sedikit muncul pada karangan anak umur 10-12 tahun di Kuningan, Jawa Barat adalah proses infiksasi karena tidak ditemukan data yang mengalami proses infiksasi.

Sebagai akibat dari adanya proses afiksasi yang mencakup prefiks, infiks, sufiks, konfiks, dan klofiks, dapat terjadi proses perubahan kelas kata yang dinamakan inflektif dan derivatif. Dalam pembentukan kata inflektif identitas leksikal kata yang dihasilkan sama dengan identitas leksikal bentuk dasarnya. Adapun pembentukan kata secara derivatif membentuk kata baru, kata yang identitas leksikalnya tidak sama dengan kata dasarnya. Dalam proses pembentukan kata derivatif identitas bentuk yang dihasilkan tidak sama dengan identitas leksikal bentuk dasarnya.

Dari data sebanyak 164 buah data ditemukan kata yang mengalami proses inflektif sebanyak 94 kata (57,3\%). Kata yang mengalami proses derivatif ditemukan sebanyak 70 kata $(42,7 \%)$. Kata yang mengalami proses inflektif lebih banyak daripada kata yang mengalami proses derivatif.

\section{KESIMPULAN}

Berdasarkan hasil analisis data mengenai proses afiksasi yang terjadi pada karangan anak umur 10-12 tahun di Kuningan, Jawa Barat, dapat ditarik kesimpulan sebagai berikut: (1) Berdasarkan hasil analisis yang dilakukan pada 20 karangan anak umur 10-12 tahun di Kuningan, Jawa Barat, ditemukan sebanyak 164 buah kata yang mengalami proses afiksasi. (2) Dari 164 buah kata yang mengalami proses afiksasi terbagi dalam enam jenis, dengan perincian: (a) prefiks: 85 buah kata, (b) infiks: 0 buah kata, (c) sufiks: 15 buah kata, (d) konfiks: 22 buah kata, dan (e) klofiks: 42 buah kata. (3) Berdasarkan 164 buah kata yang mengalami proses afiksasi dapat diketahui bahwa bentuk proses afiksasi yang paling banyak muncul pada karangan anak umur 10-12 tahun di Kuningan, Jawa Barat adalah proses prefiksasi dengan kemunculan 51,8\% dari keseluruhan data yang ditemukan. (4) Dari 164 buah kata yang mengalami proses afiksasi, tidak ditemukan data yang mengacu pada proses infiksasi. (5) Dari data sebanyak 164 buah kata ditemukan bahwa kata yang mengalami proses inflektif sebanyak 94 kata dan kata yang mengalami proses derivatif ditemukan sebanyak 70 kata. (7) Kata yang mengalami proses inflektif lebih banyak daripada kata yang mengalami proses derivatif.

\section{DAFTAR RUJUKAN}

Akhadiah, Sabarti dkk.1988. Pembinaan Kemampuan Menulis Bahasa Indonesia. Jakarta: Erlangga. 
Arkhais, Vol. 07 SNo. 2 Jufi - Desember 2016

Chaer, Abdul. 2007. Linguistik Umum. Jakarta: Rineka Cipta.

2007. Leksikologi dan Leksikografi Indonesia. Jakarta: Rineka Cipta.

2008. Morfologi Bahasa Indonesia: Pendekatan Proses. Jakarta: Rineka Cipta.

dan Leonie Agustina. 2010. Sosiolinguistik: Perkenalan Awal. Jakarta: Rineka Cipta.

Depdiknas.2008. Kamus Besar Bahasa Indonesia Pusat Bahasa.Edisi Keempat. Jakarta: Gramedia Pustaka Utama.

Keraf, Gorys. 1991. Tata Bahasa Rujukan Bahasa Indonesia. Jakarta: PT Gramedia Widiasarana.

Kridalaksana, Harimurti. 1992. Pembentukan Kata dalam Bahasa Indonesia. Jakarta: PT Gramedia Pustaka Utama.

Parera, Jos Daniel. 2007. Morfologi. Jakarta: PT Gramedia Pustaka Utama.

Pateda, Mansoer. 1989. Analisis Kesalahan. NTT: Nusa Indah.

Ramlan, M. 1987. Morfologi: Suatu Tinjauan Deskriptif. Yogyakarta: CV Karyono.

Ridwan, Sakura. 2011. Metodologi Pembelajaran Bahasa. Yogyakarta: Kepel Press.

Robins, RH. 1983. Sistem dan Struktur Bahasa Sunda. Jakarta: Djambatan.

Tarigan, Henry Guntur. 1988. Pengajaran Analisis Kesalahan Berbahasa. Bandung: Angkasa. 